\section{CITAÇÃO}

Marques, P. F. \& Pissarra, J.(2021)

Vagueando pela Mata,

Rev. Ciência Elem., V9(01):013.

doi.org/10.24927/rce2021.013

\section{EDITOR}

José Ferreira Gomes,

Universidade do Porto

\section{EDITOR CONVIDADO}

Jorge Manuel Canhoto

Universidade de Coimbra

\section{RECEBIDO EM}

27 de janeiro de 2021

\section{ACEITE EM}

27 de janeiro de 2021

\section{PUBLICADO EM}

15 de março de 2021

\section{COPYRIGHT}

(C) Casa das Ciências 2021.

Este artigo é de acesso livre, distribuído sob licença Creative

Commons com a designação

CC-BY-NC-SA 4.0, que permite a utilização e a partilha para fins não comerciais, desde que citado o autor e a fonte original do artigo.

\section{rce.casadasciencias.org}

\title{
Vagueando pela Mata
}

in casadasciencias.org/banco-imagens

Nodoso, vive quase nu, desramado pela idade que o vento avança.

Aqui cresceu, na tapada e no jardim, atravessando o céu, em terras de monges antigos que já lá não estão.

Inclina-se estranho, no socalco de cantaria, como já não coubesse nele ou espreitasse a sua origem, nas encostas do Pacífico onde 0 orvalho também rega sequoias.

Chamam-lhe "cedro" como a outros de folha parecida que não o são1, provavelmente em honra dos verdadeiros2 que inspiraram bíblias e outros testamentos.

É o cedro-do-incenso3, que aromatiza o ar pelo aperto das suas folhas, exalando um cheiro quase sagrado. Belo, já se vestiu de ramos até ao chão, e ereto, sempre verde, formou uma copa colunar densa com um pingo de amarelo.

Invulgar, especial e exótico, resiste ao seco e renasce do lume, como a azinheira, o sobreiro, o aderno4 e a Fénix.

Dramático, mas não patético, ainda exibe no seu palco os velhos ramos que restam, como se de um teatro clássico se tratasse.

\section{Paulo Farinha Marques}

Ciências/Universidade do Porto

\footnotetext{
${ }^{1}$ Géneros Cupressus, Thuja, Chamaecyparis, etc ${ }^{2}$ Género Cedrus

${ }^{3}$ Calocedrus decurrens ou Lybocedrus decurrens
} ${ }^{4}$ Phyllirea latifolia
Fustigada por tempestades que the deceparam parte da copa, esta árvore de Calocedrus decurrens na Mata do Bussaco, continua a sobreviver, não obstante parecer querer fugir do local onde a plantaram!

Calocedrus decurrens é uma espécie originária da costa Oeste da América-do-Norte, com árvores perenifólias hermafroditas que podem atingir $60 \mathrm{~m}$ de altura. Foram introduzidas na Europa como ornamentais. São resinosas, formam madeira macia e as folhas escamiformes que revestem os raminhos são aromáticas quando esmagadas. Estas árvores desenvolvem normalmente copa cónica ou quase cilíndrica.

As plantas como organismos fixos ao solo apresentam uma grande plasticidade fenotípica que lhes permite suportar alterações morfológicas ou alterar a sua fisiologia de acordo com as condições ambientais. $\mathrm{Na}$ Mata do Bussaco a única árvore de Calocedrus decurrens encontra-se próximo do $\mathrm{Pa}$ lace Hotel, a extensa desramação provocada por várias tempestades induziu um ajustamento morfológico que the possibilita continuar a viver.

\section{Mariana Coimbra de Almeida} Universidade de Aveiro 


\section{REVISTA DE CIÊNCIA ELEMENTAR}

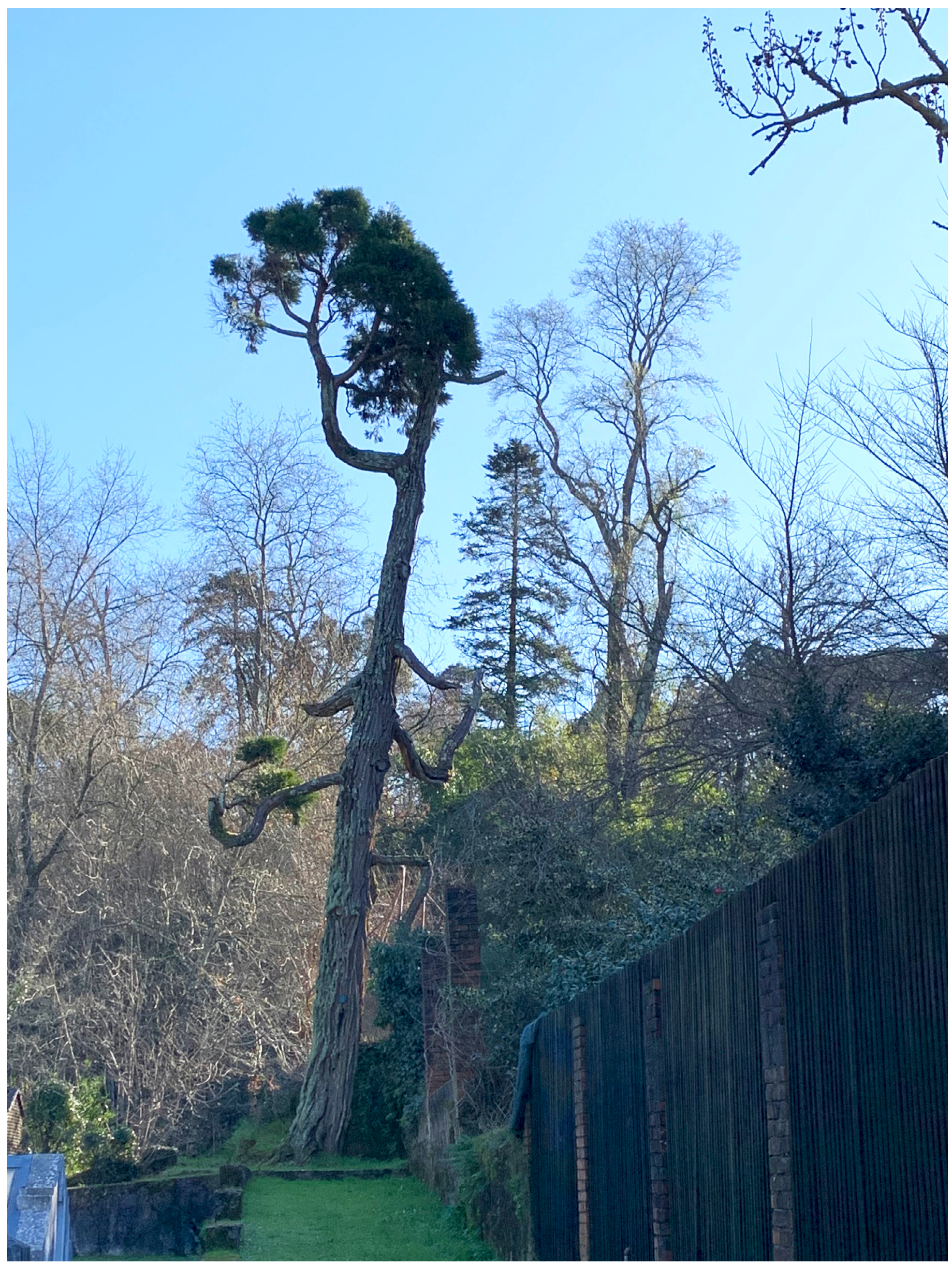

